\title{
Characterisation of Franciacorta vineyard agroecosystem to support biodiversity and ecosystem services
}

\author{
Isabella Ghiglieno ${ }^{1, *}$, Anna Simonetto ${ }^{2}$, Elia Lipreri $^{1}$, Giorgio Sperandio $^{1}$, Stefano Armiraglio ${ }^{3}$, Ivo Rigamonti $^{4}$, \\ Pierluigi Donna ${ }^{5}$, and Gianni Gilioli ${ }^{1}$ \\ ${ }^{1}$ Università di Brescia - Dipartimento di Ingegneria Civile, Architettura, Territorio, Ambiente e di Matematica - Agrofood Lab, via \\ Branze, 43, 25123 Brescia, Italy \\ ${ }^{2}$ Università di Brescia - Dipartimento di medicina molecolare e traslazionale - Agrofood Lab, viale Europa, 11, 25121 Brescia, Italy \\ ${ }^{3}$ Museo Civico di Scienze Naturali - Sez. di Botanica, via Ozanam 4, 25128 Brescia, Italy \\ ${ }^{4}$ Università degli Studi di Milano - Dipartimento di Scienze per gli Alimenti, la Nutrizione e l'Ambiente, via Celoria 2, 20133, \\ Milano, Italy \\ ${ }^{5}$ Sata Studio Agronomico S.r.l. - S.t.p., Piazza della Loggia 5, 25121, Brescia, Italy
}

\begin{abstract}
Vineyard is a multifunctional ecosystem associated to a multitude of environmental benefits and ecosystem services. Despite the increased research efforts on the analysis of biodiversity patterns and ecosystem services in vineyard, the lack of approaches to multifunctionality suggests to develop integrated approaches allowing to manage the complexity of vineyard landscape. The present study introduces an innovative methodology aimed at developing a unitary framework able to describe vineyard ecosystems biodiversity considering both local (morphological characteristics, internal ecological infrastructure, and management) and landscape (land-use) components. The case of Franciacorta wine-growing area is described considering a total of 112 ha located in three wine companies. Four informative layers related to different components of Franciacorta territory were defined: i) morphology; ii) internal ecological infrastructure; iii) landscape composition; iv) management. This study provides a useful instrument to increase knowledge about vineyard system biodiversity and to protect ecosystem services provision in Franciacorta territory. The methodology applied can easily be extended to the whole wine-growing compartment.
\end{abstract}

\section{Introduction}

Viticulture is among the oldest and most representative forms of agriculture, covering about 7.3 million hectares worldwide [1]. Vineyards strongly shape the appearance of landscapes in a territory [2,3]. The vineyard is a multifunctional ecosystem [4] associated with a multitude of ecosystem services, performing important economic, cultural, and ecological roles. Winkler et al. [5] identified 27 ecosystem services classes associated with vineyards; among them the most investigated resulted: cultivated crops, sequestration, pest control, disease control, scientific, and heritage, cultural services. Biodiversity represents a key actor in the provisioning of these ecosystem services in the vineyard ecosystem, both at local (vineyard and the areas adjacent to vineyards) and, more extensively, at landscape level [6]. In this context, research efforts on the relationships between biodiversity patterns and ecosystem services in vineyards increased [5]. However, most of the studies addressed specific issues related to biodiversity while few studies adopted approaches to multifunctionality in vineyards [4].

The complexity of the vineyard landscape imposes to perform innovative integrated approaches allowing to define a systemic analysis of vineyards agroecosystems [7], including both local and landscape elements, evaluated at different temporal and spatial scales.

In the present study, an innovative methodology is proposed to develop a unitary framework able to describe vineyard agroecosystem's biodiversity considering all local (morphological characteristics, internal ecological infrastructure, and management) and landscape (land-use) components.

The methodology is applied to the case study of the Franciacorta wine-growing area (Lombardy, Italy). Franciacorta is one of the most important Italian winegrowing regions for sparkling wine production. There, farmers are aware of issues related to biodiversity and eco-tourism represents an important resource. Results obtained from this preliminary study set the ground for specific monitoring activities addressing the main components of biodiversity, providing a useful instrument for wine growing companies and the whole Franciacorta territory to increase knowledge about vineyard agroecosystem and to protect ecosystem services provision. This case study represents a virtuous example for the wine-growing compartment promoting a

* Corresponding author: i.ghiglieno@unibs.it 
multifunctional perspective of the vineyard ecosystem, supporting long-term sustainable use of natural resources.

\section{Materials and methods}

\subsection{Study area}

The research was promoted by the Consorzio per la tutela del Franciacorta. Franciacorta territory includes a total of 3299 ha of vineyards, 2902 of which are dedicated to Franciacorta DOCG sparkling wines production. To perform a preliminary characterisation of the landscape of Franciacorta wine territory, an area of 112 ha of vineyards was considered.

\subsection{Environmental Units identification}

The analyzed area was split into several units, hereinafter Environmental units (EUs), defined as a whole vineyard or portion of vineyard homogenous in terms of four agronomic characteristics: planting year, planting density, cultivar, and training system. EUs identification was performed using the Geographic Information System (GIS). In particular, the area of each EU was defined as a polygon based on the classification of the vineyards in the land-cover/land-use map of the Lombardy region (DUSAF v6.0 2018, 'Destinazione d'Uso dei Suoli Agricoli e Forestali', freely available online from the geoportal of the Lombardy region 'Geoportale della Lombardia' - GOL [8]).

\subsection{Environmental Units characterisation}

EUs were characterized by local and landscape components organized in four different informative layers: i) morphology; ii) internal ecological infrastructure, iii) landscape composition; iv) management.

\subsubsection{Morphological characterisation}

In the morphological layer, altitude, slope, aspect, row orientation, and solar irradiance were used to characterize the EUs.

Altitude (meters above sea level) was calculated using the elevation raster, with pixel $5 \mathrm{~m} \mathrm{x} 5 \mathrm{~m}$, freely available online in GOL. Slope (expressed in degrees) is the mean angle of inclination to the horizontal of the EU. Aspect (expressed in degrees, from $0^{\circ}$ to $360^{\circ}$ starting from the North) is the compass direction that the EU slope faces. Slope and aspect values were computed using an opensource GIS software [9] based on the GOL elevation raster. Solar irradiance was calculated using the model r.sun (based on Krcho [10] later improved by Jenco [11]) that estimates the daily sum of solar irradiation $\left[\mathrm{Wh}^{*} \mathrm{~m}^{-}\right.$ $2 *$ day $^{-1}$ ]. Model for solar irradiance was implemented in an open-source GIS software [12] using topographic factors obtained from the GOL elevation raster. We computed this model for the June 2020 solstice (171st day of the year). Values of altitude, slope, aspect, and solar irradiance were calculated as the average value of all raster pixels inside the polygon of the EU. Row orientation was obtained by digitilising one or many rows of vines in each EU. Cosine of the angle between azimuth and each row (expressed in degrees) were obtained in the GIS environment [9]. High values (near 1) indicate N-S orientation while low values (near 0 ) E-W orientation.

\subsubsection{Internal ecological infrastructures}

EUs internal ecological infrastructures were characterised based on photointerpretation from of high scale (1:2.000) regional orthophotos (GOL) and manual digitalisation of structural elements.

Two types of structural elements were considered: punctual (points) and areal elements (polygons) [6]. Punctual elements (e.g. isolated trees) were digitalised, counted, and reported as the number of elements per $\mathrm{m}^{2}$ of EU area. Areal elements (e.g. Grassland) were digitalised as polygons, computed through polygon area, and reported as $\mathrm{m}^{2}$ of areal elements per $\mathrm{m}^{2}$ of EU area. Each areal element was classified using EUNIS habitat type classification [13] as suggested by Kratschmer et al. [14].

The characterisation of internal ecological infrastructures was conducted in the EU area plus a small buffer zone with a radius of 5 meters around the EU.

\subsubsection{Landscape composition}

Landscape composition was characterised in a buffer area of a radius of 500 meters around the EU. The percentage of buffer area covered by each land-use category identified using DUSAF was calculated.

\subsubsection{Management practices}

Information about the management practices of each EU was collected through a survey carried out at each of the wine companies involved in the project. The survey was referred to the agricultural year 2019-2020 and included information on management regime, canopy management, and ground management.

In the study, six variables related to inter-row ground management were considered. Sown cover crop, fertilisation, fertilisation with pellet fertiliser, fertilisation with organic fertiliser as compost or manure, mowing managed in alternated rows were represented by binary variables $(0=$ no adoption of the practice, $1=$ adoption). Times of tillage was identified as an integer variable (form $0=$ no-tillage to $5=5$ times tillage).

\subsection{Data analysis}

To identify homogeneous EU units according to the characteristics defined for each information layer, a cluster analysis was performed. The adequate clustering model and the optimal number of clusters for each layer were selected evaluating the silhouette plot (function eclust, package factoextra [15] of the software R). The 
Euclidean distance and the Ward method were used for the analysis.

\section{Results and discussion}

\subsection{Environmental Unit identification}

In the 112 ha of vineyards, 108 EUs were identified. The average area of EUs resulted equal to $0.96 \pm 0.76$ ha ranging from 0.09 ha to 4.96 ha.

\subsection{Environmental Unit characterisation}

\subsubsection{Morphological characterisation}

Franciacorta morphology is heterogeneous [16], as shown by the variability of all morphological characteristics in the EUs (Table 1).

Table 1. Descriptive statistics of morphological variables in the 108 EUs.

\begin{tabular}{|c|c|c|c|}
\hline Variables & Units & Mean \pm SD* & $\begin{array}{c}\text { Range } \\
\text { [min, max] }\end{array}$ \\
\hline Altitude & m a.s.1. & $229.81 \pm 37.37$ & $133.71-318.22$ \\
\hline Aspect & $\circ$ & $181.32 \pm 64.93$ & $44.64-311.22$ \\
\hline Slope & $\circ$ & $6.75 \pm 5.80$ & $0.51-31.06$ \\
\hline $\begin{array}{c}\text { Solar } \\
\text { irradiance }\end{array}$ & $\begin{array}{c}\mathrm{Wh}^{*} \mathrm{~m}^{-2} \\
\text { day }^{-1}\end{array}$ & $8819.29 \pm 70.89$ & $\begin{array}{c}8554.91- \\
8907.06\end{array}$ \\
\hline $\begin{array}{c}\text { Row } \\
\text { orientation }\end{array}$ & pure number & $0.68 \pm 0.32$ & $0.01-1.00$ \\
\hline
\end{tabular}

* SD: standard deviation

Clustering analysis identified five groups of EUs homogeneous by morphological characteristics (Fig. 1).

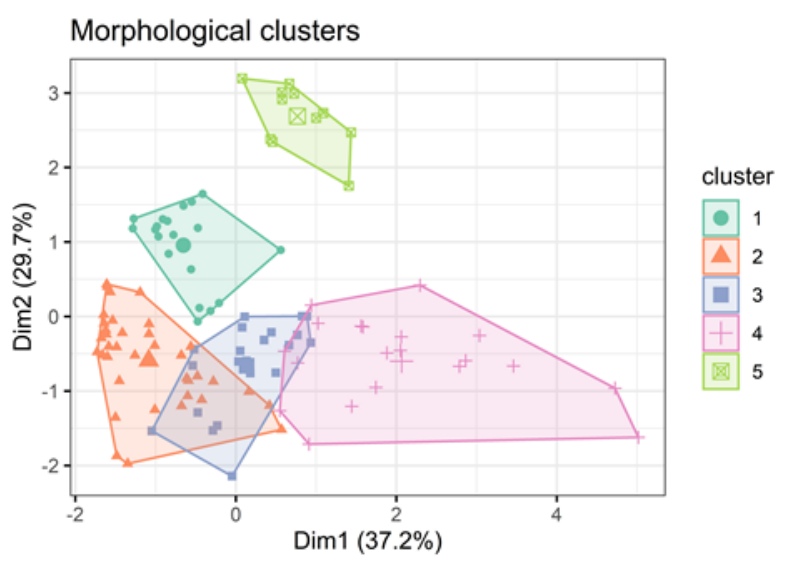

Fig. 1. Cluster plot related to morphological variables.

All morphological variables are well discriminated among clusters. For instance, the differences in slope and aspect values according to clusters are reported in Fig. 2.

We focused on slope and aspect due to their fundamental role in the determination of hydraulic condition [17] and evapotranspiration in vineyards [18].
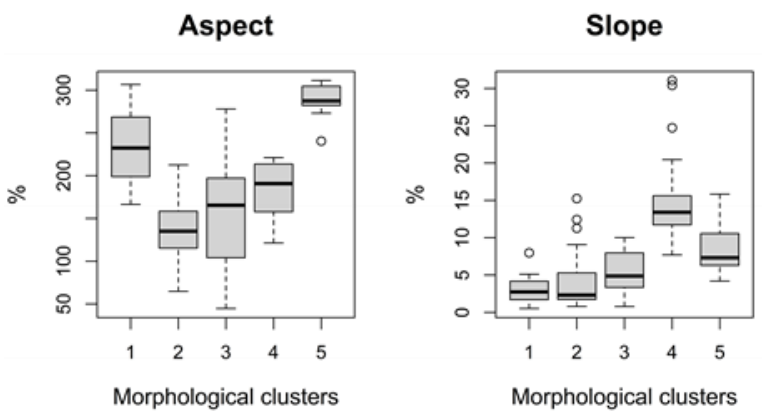

Fig. 2. Boxplots representing the distribution of values of Aspect (left) and Slope (right) in the 108 EUS according to the five clusters identified.

\subsubsection{Internal ecological infrastructures}

Ecological infrastructures play an important role in maintaining biodiversity in vineyard agroecosystems [19]. EUs characterisation allowed to identify eight internal ecological infrastructures (Table 2).

Table 2. Descriptive statistics of internal ecological infrastructure variables.

\begin{tabular}{|c|c|c|c|}
\hline \multicolumn{4}{|c|}{ Punctual elements (number* $\mathbf{m}^{-2}$ ) } \\
\hline Code & Definition & $\begin{array}{l}\text { Mean } \\
\pm \text { SD* }^{*}\end{array}$ & $\begin{array}{c}\text { Range } \\
{[\mathrm{min}, \mathrm{max}]}\end{array}$ \\
\hline $\begin{array}{l}\text { Isolated } \\
\text { trees }\end{array}$ & $\begin{array}{l}\text { Number of isolated } \\
\text { trees }\end{array}$ & $\begin{array}{c}0.000 \\
\pm 0.000\end{array}$ & $0.000-0.003$ \\
\hline $\begin{array}{l}\text { Disconti } \\
\text { nuous } \\
\text { row }\end{array}$ & $\begin{array}{l}\text { Number of trees in a } \\
\text { discontinuous row }\end{array}$ & $\begin{array}{c}0.000 \\
\pm 0.001\end{array}$ & $0.000-0.007$ \\
\hline \multicolumn{4}{|c|}{ Areal elements $\left(\mathbf{m}^{2 *} \mathbf{m}^{-2}\right)$} \\
\hline $\begin{array}{c}\text { EUNIS } \\
\text { Code }\end{array}$ & Definition & $\begin{array}{l}\text { Mean } \\
\pm \mathrm{SD}^{*}\end{array}$ & $\begin{array}{c}\text { Range } \\
{[\mathrm{min}, \mathrm{max}]}\end{array}$ \\
\hline E & $\begin{array}{lr}\text { Grasslands } & \text { (excluding } \\
\text { vineyard } & \text { interrow } \\
\text { vegetation) } & \end{array}$ & $\begin{array}{c}0.091 \\
\pm 0.160\end{array}$ & $0.000-1.033$ \\
\hline G2.91 & Olea europaea groves & $\begin{array}{c}0.031 \\
\pm 0.110\end{array}$ & $0.000-0.736$ \\
\hline G5 & $\begin{array}{l}\text { Lines of trees, small } \\
\text { anthropogenic } \\
\text { woodlands }\end{array}$ & $\begin{array}{c}0.035 \\
\pm 0.062\end{array}$ & $0.000-0.325$ \\
\hline $\mathrm{J} 2$ & Low density buildings & $\begin{array}{c}0.001 \\
\pm 0.003\end{array}$ & $0.000-0.023$ \\
\hline $\mathrm{J} 4$ & $\begin{array}{l}\text { Transport networks and } \\
\text { other constructed hard- } \\
\text { surfaced areas }\end{array}$ & $\begin{array}{c}0.016 \\
\pm 0.062\end{array}$ & $0.000-0.581$ \\
\hline $\mathrm{J} 5$ & $\left|\begin{array}{lcc}\text { Highly } & \text { artificial } & \text { man- } \\
\text { made } & \text { waters } & \text { and } \\
\text { associated structures. }\end{array}\right|$ & $\begin{array}{c}0.000 \\
\pm 0.001\end{array}$ & $0.000-0.011$ \\
\hline
\end{tabular}

* SD: standard deviation

The 108 EUs were classified into two clusters according to internal ecological infrastructures (Fig. 3). 


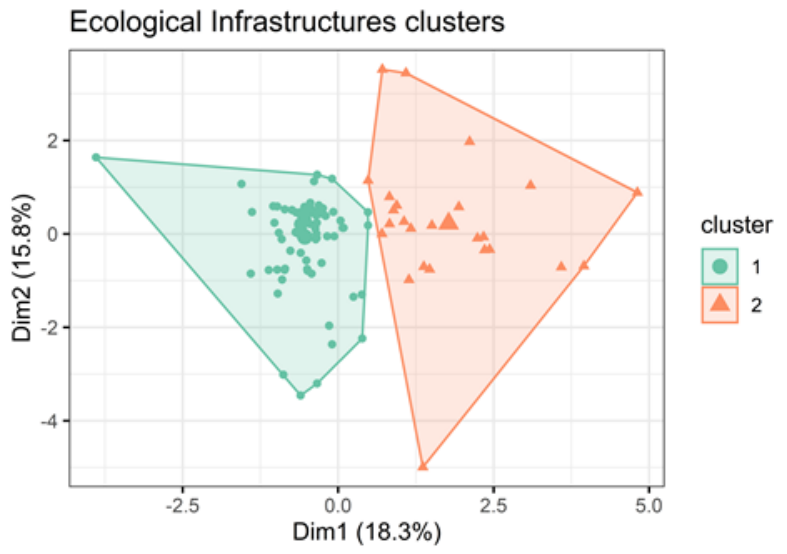

Fig. 3. Cluster plot related to internal ecological infrastructure variables.

Cluster 1 includes 83 EUs characterised by a higher abundance of internal ecological infrastructures compared to EUs included in Cluster 2. This is particularly evident considering the presence of Isolated trees and Grassland (Fig. 4). These ecological infrastructures are related to important ecosystem functions as pest control and pollination services. Assandri et al. [20] emphasised the role of isolated trees in providing nesting sites, while Kratschmer et al. [14] reported an increase in the abundance of solitary wild bees in vineyards with a higher presence of isolated trees. Grasslands (which include grass strips and floral strips) provide benefits to many mobile ecosystem service providers as predators, parasitoids and pollinators [19].

Isolated trees

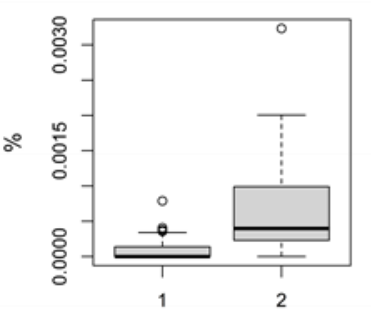

Ecological infrastractures clusters

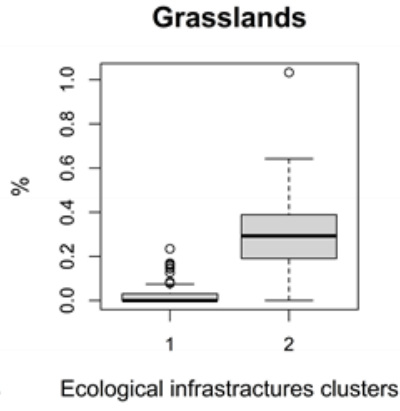

Fig. 4. Boxplots representing the distribution of values of Isolated trees (left) and Grassland (right) in the 108 EUs according to the two clusters identified.

\subsubsection{Landscape composition}

A higher level of landscape heterogeneity can reduce biodiversity decline in vineyard ecosystems [21], contrasting the landscape simplification deriving from the intensification of monoculture. In the buffer areas around the 108 EUs, 19 different land-use categories were identified (Table 3).

The land-use categories most present in the landscape of the EUs were non-irrigated arable land, vineyards, pastures, residential or industrial units, broad-leaved forest.

EUs were classified into three clusters according to landscape composition (Fig. 5).
Table 3. Descriptive statistics of landscape variables in the buffer areas of the 108 EUs.

\begin{tabular}{|c|c|c|c|}
\hline Code & Definition & $\begin{array}{c}\text { Mean } \pm \text { SD* } \\
(\%)\end{array}$ & $\begin{array}{c}\text { Range [min, } \\
\max ](\%)\end{array}$ \\
\hline AGRC01 & $\begin{array}{l}\text { non-irrigated } \\
\text { arable land }\end{array}$ & $20.52 \pm 12.98$ & $0.00-48.82$ \\
\hline AGRC02 & $\begin{array}{l}\text { horticultural } \\
\text { crops }\end{array}$ & $0.17 \pm 0.37$ & $0.00-1.80$ \\
\hline AGRC03 & protected crops & $0.01 \pm 0.07$ & $0.00-0.54$ \\
\hline AGRC04 & $\begin{array}{l}\text { floricultural } \\
\text { crops }\end{array}$ & $0.74 \pm 1.16$ & $0-4.13$ \\
\hline AGRC05 & vineyards & $36.30 \pm 12.61$ & $11.81-63.56$ \\
\hline AGRC06 & $\begin{array}{l}\text { fruit trees, } \\
\text { berry } \\
\text { plantations }\end{array}$ & $0.15 \pm 0.36$ & $0.00-2.41$ \\
\hline AGRC07 & olive groves & $1.10 \pm 1.34$ & $0.00-4.99$ \\
\hline AGRC08 & other orchards & $0.59 \pm 0.86$ & $0.00-2.33$ \\
\hline AGRC09 & pastures & $4.06 \pm 5.26$ & $0.00-26.64$ \\
\hline ANTR01 & $\begin{array}{l}\text { residential or } \\
\text { industrial units }\end{array}$ & $13.84 \pm 7.51$ & $2.43-35.37$ \\
\hline ANTR02 & $\begin{array}{l}\text { isolate } \\
\text { buildings }\end{array}$ & $0.70 \pm 0.62$ & $0.00-4.15$ \\
\hline ANTR03 & $\begin{array}{l}\text { road, rail } \\
\text { networks and } \\
\text { associated land }\end{array}$ & $0.51 \pm 1.04$ & $0.00-4.72$ \\
\hline ANTR04 & $\begin{array}{l}\text { green urban } \\
\text { areas }\end{array}$ & $1.03 \pm 1.10$ & $0-4.60$ \\
\hline ANTR05 & $\begin{array}{l}\text { other artificial } \\
\text { units }\end{array}$ & $1.13 \pm 1.85$ & $0.00-11.48$ \\
\hline BOSC01 & $\begin{array}{l}\text { broad-leaved } \\
\text { forest }\end{array}$ & $16.65 \pm 13.11$ & $0.00-71.28$ \\
\hline IDRC01 & water bodies & $0.07 \pm 0.12$ & $0.00-0.39$ \\
\hline SNAT01 & $\begin{array}{l}\text { near-rivers } \\
\text { broad-leaved } \\
\text { woodlands } \\
\end{array}$ & $2.08 \pm 2.07$ & $0.00-9.51$ \\
\hline SNAT02 & inland marshes & $0.02 \pm 0.21$ & $0.00-2.23$ \\
\hline SNAT03 & $\begin{array}{l}\text { transitional } \\
\text { woodland- } \\
\text { shrub }\end{array}$ & $0.32 \pm 0.52$ & $0.00-1.87$ \\
\hline
\end{tabular}

* SD: standard deviation

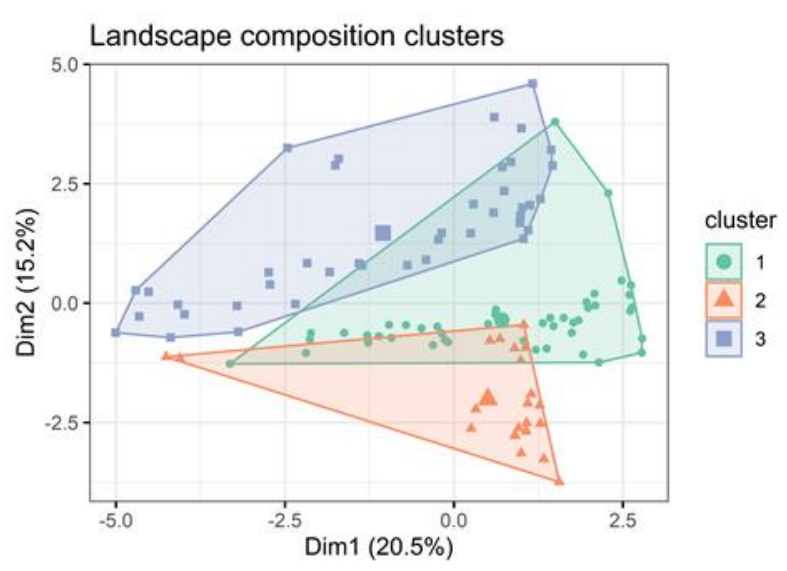

Fig. 5. Cluster plot related to landscape variables. 
The distributions of the percentage of buffer area covered by vineyards and broad-leaved forests (Fig. 6) are an example of the composition differences between the EU landscapes. Although EUs characterised by landscapes mainly occupied by vineyards (Cluster 2) can be negatively influenced in their biodiversity [6], this general consideration should be deepened including information about internal vineyards characterisations and other landscape components. Forest areas represent a potential source habitat for many functional guilds and are usually linked to a greater landscape heterogeneity [22].
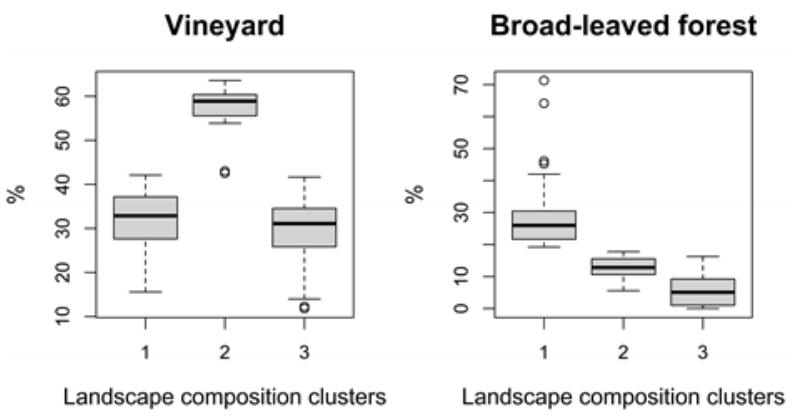

Fig. 6. Boxplots representing the distribution of values of Vineyard (left) and Broad-leaved Forest (right) in the 108 EUs according to the three clusters identified.

\subsubsection{Management}

Many studies focused on the role of vineyard management in influencing biodiversity and related ecosystem functions [6]. Specifically, the role of ground management practices has been emphasised [4].

Two groups of EUs were identified considering management practices (Fig. 7).

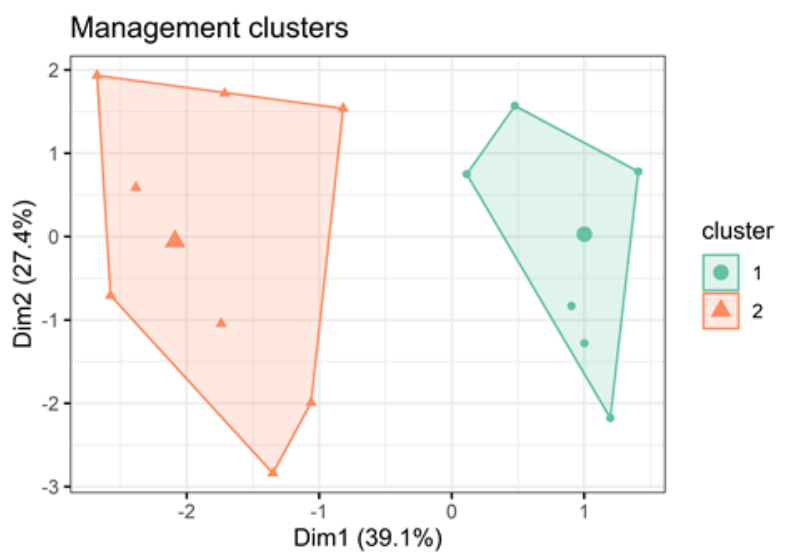

Fig. 7. Cluster plot related to Management variables.

Fig. 8 shows the frequency distribution of the six management practices in the two clusters. Cluster 1 included EUs not tilled or tilled once, while cluster 2 included EUs tilled from 0 to 5 times.

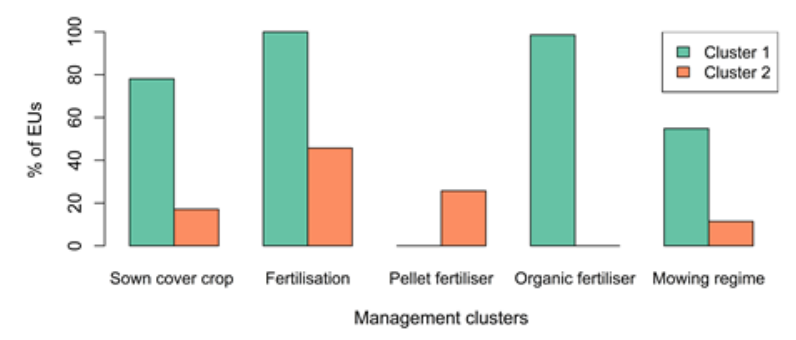

Fig. 8. Distribution of EUs (\%) in each cluster according to interrow ground management binary variables.

\section{Conclusion}

In this study, an innovative methodology to develop a framework for a systemic approach to vineyard agroecosystem is presented. This integrated approach to the assessment of vineyard biodiversity allows managing the complexity of the vineyard landscape.

The case study of the Franciacorta wine-growing area is reported. Different components of local (within vineyard) and landscape biodiversity are presented in separated informative layers to obtain a detailed description of Franciacorta wine-growing area territory.

This study set the ground for carrying out specific monitoring activities addressing the main components of biodiversity, providing a useful instrument to increase knowledge about vineyard system biodiversity.

We thank the 'Consorzio per la tutela del Franciacorta', which promoted this Project, and the wine Companies assisting with data collection.

\section{References}

1. OIV. http://www.oiv.int/en/technical-standards-anddocuments/statistical-analysis/state-ofvitiviniculture (accessed on 26 August 2021).

2. M.A. Altieri, C.I. Nicholls. Agrofor. Syst. 56 (3), 185-191 (2002)

3. G. Barbera, S. Cullotta. In: Biocultural Diversity in Europe. Environmental History 5 (Springer, Cham. 2016)

4. S. Winter, T. Bauer, P. Strauss, et al. Appl Ecol. 55, 2484-2495 (2018)

5. K.J. Winkler, J.H. Viers, K.A. Nicholas. Front. Environ. Sci. 5, 15 (2017)

6. A. Paiola, G. Assandri, M. Brambilla, M. Zottini, P. Pedrini, J. Nascimbene. Sci. of the Total Environ. 706, 135839 (2020)

7. I. C. Vasiliță-Crăciun, C.I. Gavra. Rom. Rev. Reg. Stud. XII (1), 79-90 (2016)

8. Geoportale della Lombardia. https://www.geoportale.regione.lombardia.it/ 
9. QGIS Development Team. http://qgis.osgeo.org. (2021).

10. J. Krcho. VEDA, Bratislava. (1990).

11. M. Jenco. Geograficky casopis 44, 342-355 (1992)

12. GRASS Development Team. https://grass.osgeo.org. (2020).

13. European Environment Agency (EEA), http://eunis.eea. europa.eu/habitats.jsp (accessed 29 September 2016).

14. S. Kratschmer, B. Pachinger, M. Schwantzer, D. Paredes, M. Guernion, F. Burel, A. Nicolai, P. Strauss, T. Bauer, M. Kriechbaum, J. G. Zaller, \& S. Winter. Agric. Ecosys. Environ. 266, 142-152 (2018)

15. A. Kassambara and F. Mundt factoextra. R package version 1.0.7. (2020).

16. R. Minelli. La Zonazione della Franciacorta, 28 (1997)

17. M. Tanadini, B. R.Schmidt, P. Meier, J. Pellet, N. Perrin. Anim. Conserv. 15, 136-141 (2012)

18. T. M. Shapland, R. L. Snyder, D. R. Smart, L. E. Williams. Irrig Sci 30, 471-484 (2012)

19. N. Rosas-Ramos, L. Baños-Picón, J. Tormos, J.D. Asís. Ann Appl Biol. 175, 193-201 (2019)

20. G. Assandri, G. Bogliani, P. Pedrini, M. Brambilla. Ecol. Indic. 80, 275-285 (2017)

21. D. Paredes, J. A. Rosenheim, R. Chaplin-Kramer, S. Winter, D. S. Karp. Ecol. Lett., 24, 73-83 (2021)

22. E. Caprio, B. Nervo, M. Isaia, G. Allegro, A. Rolando. Agric. Syst. 136, 61-6 (2015) 